\title{
10.1515/rjes -2016-0013
}

\section{PHRASE STRUCTURE PATTERNING AND LICENSING FOR ENGLISH AND SERBIAN SPEAKER-ORIENTED ADVERB SUBCLASSES}

\author{
GORDANA DIMKOVIĆ-TELEBAKOVIĆ \\ University of Belgrade
}

\begin{abstract}
This paper attempts to set phrase structure rules for English and Serbian speaker-oriented adverb subclasses. Adverbs are looked at here as specifiers licensed by the semantic feature [ILLOCUTIONARY FORCE]. The results suggest that illocutionary, evaluative and evidential adverbs normally merge within the complementizer layer and the inflectional layer, and that English epistemic adverbs are in most cases preferably integrated into the inflectional layer, whereas Serbian epistemic adverbs tend to occur in the sentence-initial position.

Keywords: speaker-oriented adverbs in English and Serbian, their distribution and semantics, the functional specifier analysis and head feature licensing approach
\end{abstract}

\section{Introduction}

The issue of adverb patterning and licensing has been closely analysed in linguistic theory basically within the framework of two distinct types of analysis of the interplay between adverb syntax and semantics. Proponents of the functional specifier analysis (cf. Laenzlinger 1996, 1998; Alexiadou 1997; Cinque 1999, 2004, among others) state that syntax determines semantics, whereas proponents of the adjunction approach (cf. Frey and Pittner 1999; Haider 2000, 2004; Ernst 2000, 2002, 2004a, 2004b, for instance) believe that semantics determines syntax. Linguists also differently explain the integration of adverbs into clause structure. If adverbs have argument status, they are considered to be complements. McConnell-Ginet (1982), Larson (1988) and Alexiadou (1997) analyse temporal, spatial, manner and completion adverbs as complements. Chomsky (1986:6) maintains that adjunction is possible only to a nonargument. Ernst (2002:67) shows, for example, that manner adverbs can merge into syntax as VP adjuncts if placed on a left-branch. Degree elements, quantifiers and negative constituents have been recategorized as functional heads. Rakowski and Travis (2000) view postverbal adverbs as functional heads (e.g. She could investigate no longer). Kayne (1994) illustrates that adverbs can integrate into syntactic structure as complements or specifiers. Cinque (1999) establishes canonical order of adverbs and claims that they merge into syntax as unique specifiers of designated functional projections. As speaker-oriented adverbs specify the whole proposition, they will be looked at in this paper as specifiers.

The main research objective of this study is to reveal structure patterning and licensing for speaker-oriented adverbs, i.e. their subclasses - illocutionary adverbs, evaluative adverbs, evidential adverbs and epistemic adverbs, and their base positions in the two languages under scrutiny. We assume that this investigation will help us establish phrase structure rules for 
English and Serbian speaker-oriented adverb subclasses, and better understand the interplay between adverb syntax and semantics. The analysis is expected to show that adverb distribution in Serbian is more flexible than in English, and that English and Serbian adverbs do not basically overlap structurally. The theoretical concepts and key terms employed will be defined in the following sections.

\section{Corpus, Method and Analysis}

The corpus of this study is mainly built from English examples extracted from the BNC. Examples in English were selected based on speaker-oriented adverb positions in syntactic structure. Sentences in Serbian are translations of English examples.

The functional specifier analysis (see Cinque 1999; Haumann 2007) and head feature licensing approach (see Travis 1988) are employed to consider the interplay between adverb syntax and semantics. Throughout this paper, it has been assumed that each functional projection has its own specific semantic interpretation, and that adverbs enter into transparent semantic relations with the head of the functional projection they occur in. (For more details see Cinque 1999).

The starting point of the analysis is that adverbs have phrasal status. In accordance with this, certain abbreviations are used in the text. Some of them are specForce(Fin)P, which stands for specifier Force (Finite) Phrase, specEvalP - specifier Evaluative Phrase, specEvidP specifier Evidential Phrase, IP - Inflection Phrase, where Inflection is the sentence, ForceP Force Phrase, which hosts illocutionary adverbs, EvalP - Evaluative Phrase, where evaluative adverbs sit, EvidP - Evidential Phrase, into which evidential adverbs are merged, EpiP Epistemic Phrase, where epistemic adverbs occur, CP - Complementizer Phrase, NegP sentence-negating phrase, etc. The phrases ForceP, EvalP, EvidP and EpiP represent, thus, the licensing sites of adverbs, with adverbs entering into a transparent semantic relationship with their licensing functional heads.

Co-occurrences of adverbs are not explored here, though they certainly deserve thorough examination to help us better understand adverb licensing (see, for instance, Cinque 1999, 2004; Ernst 2002; Haumann 2007; Dimković-Telebaković 2011; Dimković-Telebaković 2013; Dimković-Telebaković 2015).

In Section 2.1, we discuss different speaker-oriented adverb subclasses. The results of the investigation presented in this paper are summarised in Section 3.

\subsection{Speaker-oriented Adverbs and Their Patterning in English and Serbian}

Speaker-oriented adverbs have received this label because they express the speaker's attitude to the event denoted by the sentence (cf. Jackendoff 1972:56). They are also called pragmatic adverbs (cf. Bellert 1977:349) or stance adverbs (see Biber et al. 1999). As speakeroriented adverbs are syntactically and semantically heterogeneous, we follow Bellert's (1977:341ff.) classification mainly based on semantic criteria, and examine a number of illocutionary adverbs, evaluative adverbs, evidential adverbs and epistemic adverbs here. The strings below show that speaker-oriented adverbs are licensed by the semantic feature [ILLOCUTIONARY FORCE] (cf. Travis 1988:290), and how they may pattern in English and Serbian. 


\subsubsection{Illocutionary Adverbs}

Bellert (1977:349ff.) maintains that illocutionary adverbs either specify the content of the proposition (e.g. honestly, frankly - honestly-type adverbs) or the way in which it is expressed, i.e. the form (e.g. briefly, roughly - briefly-type adverbs). To corroborate the assumption that illocutionary adverbs sit in specForce(Fin)P and are licensed under specifier-head agreement, Haumann (2007:339) illustrates that they fail to occur within the scope of relative operators (e.g. * On the way down I fell over a man hiding in a dark corner, who roughly ran away immediately), conditional operators (e.g. *Had she not been so downhearted briefly Ruth would have enjoyed herself) and interrogative operators (e.g. *I wonder if frankly that would have helped). These examples show that illocutionary adverbs depend on Force-related features, and that can be analysed as assertive operators.

Sentences (1e) and (1s a, b) demonstrate that the illocutionary adverbs (ForceP) frankly/iskreno, otvoreno may be used in the sentence-initial position, i.e specForce(Fin)P. If this is the case, it is significant to say that Serbian sentence patterning allows the subject omission, as shown in $(1 s b),(2 s b),(3 s b),(4 s b),(5 s b)$ and $(9 s b)$, whereas English structure patterning does not.

(1e) Frankly, I don't have much faith in the aunt.

$\mathrm{IP} \rightarrow$ ForceP $-\mathrm{NP}-\mathrm{AuxP}-\mathrm{V}-\mathrm{NP}-\mathrm{PP}$

(1s) a. Iskreno / Da kažem otvoreno, ja nemam mnogo poverenja u tetku.

$\mathrm{IP} \rightarrow$ ForceP / $\quad$ ForceP $-\mathrm{NP}-\mathrm{V}-\mathrm{NP} \quad-\mathrm{PP}$

(1s) b. Iskreno / Da kažem otvoreno, nemam mnogo poverenja u tetku.

$\mathrm{IP} \rightarrow$ ForceP / ForceP $-\mathrm{V}-\mathrm{NP} \quad-\mathrm{PP}$

In sentence (2e), frankly assumes the post-subject position, while otvoreno in example (2s a) occurs within the inflectional layer, and in $(2 s b)$ in the front sentence position.

(2e) He frankly admitted to being obsessed with her sex ...

$\mathrm{IP} \rightarrow \mathrm{NP}-$ ForceP $-\mathrm{V}-\mathrm{VP}-\mathrm{PP}$

(2s) a. On je otvoreno priznao da je opsednut njenom privlačnošću ...

$\mathrm{IP} \rightarrow \mathrm{NP}-\mathrm{AuxP}-$ ForceP $-\mathrm{V}-\mathrm{VP} \quad-\mathrm{NP}$

(2s) b. Otvoreno je priznao da je opsednut njenom privlačnošću ...

$\mathrm{IP} \rightarrow$ ForceP - AuxP $-\mathrm{V}-\mathrm{VP} \quad-$ NP

Frankly can also appear after the finite non-lexical verb, as in (3e). The adverbs neskriveno and iskreno are realized within the inflectional layer too, which is illustrated by ( $3 \mathrm{~s} \mathrm{a}$, b). Sentence (3e) has two meanings here, since frankly baffled may be translated as neskriveno osujećen or iskreno zbunjen. Example ( $3 \mathrm{~s} \mathrm{~b})$ Bio je iskreno zbunjen shows that if a sentence contains no subject it can open with a verb in Serbian. Further investigation into adverbs in this paper will demonstrate that Serbian typically patterns in this way.

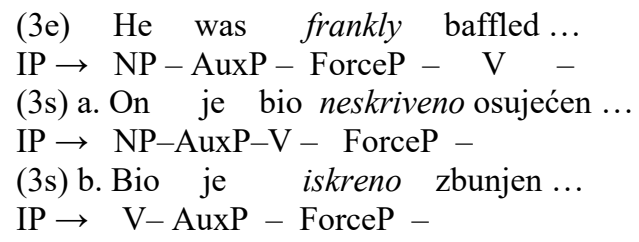

In strings (4e) and (4s a, b), we show that these illocutionary adverbs may follow the finite non-lexical verb, and have different structure patterning in the two languages. 
(4e) They can frankly ask him for a favour.

$\mathrm{IP} \rightarrow \mathrm{NP}-$ AuxP-ForceP-V-NP - PP

(4s) a. Oni ga mogu otvoreno zamoliti za uslugu.

$\mathrm{IP} \rightarrow \mathrm{NP}-\mathrm{NP}-$ AuxP-ForceP - V $\quad$-PP

(4s) b. Mogu ga otvoreno zamoliti za uslugu.

$\mathrm{IP} \rightarrow$ AuxP-NP-ForceP - V $-\mathrm{PP}$

If we compare examples (2e) and (4e) with Haumann's (2007:342f.) examples, containing subject-oriented adverbs and subject-attitude adverbs, we can see that Haumann is right in claiming that frankly-type illocutionary adverbs, i.e. honestly-type illocutionary adverbs, overlap with subject-oriented adverbs and subject-attitude adverbs. This comparison confirms Haumann's findings and shows that it is not easy to identify base positions for different adverb subclasses, since they may overlap.

Strings $(5 \mathrm{e})$ and $(5 \mathrm{~s} \mathrm{a}, \mathrm{b})$ illustrate that frankly-type illocutionary adverbs may be found in the final-sentence position too, but we must point out that sentence $(5 \mathrm{~s}$ b) sounds more natural in Serbian than $(5 \mathrm{~s}$ a). In contrast, sentence (5e) shows that English does not allow structure patterning which excludes the subject of the sentence.

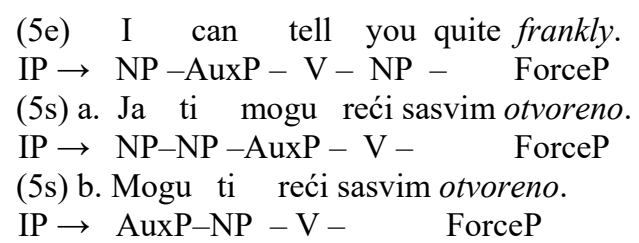

Examples (6e) and (6s a, b) contain the illocutionary adverbs honestly and iskreno. These sequences show that the adverbs may assume the initial sentence position when they precede focalized expressions, but cannot follow such expressions. Haumann (2007:340) also provides evidence to support this claim, and illustrates that illocutionary adverbs cannot follow topicalized constituents, but can precede them. This confirms her assumption that illocutionary adverbs are inmates of specForce(Fin)P. Sentences $(6 s \mathrm{a}, \mathrm{b})$, on the other hand, demonstrate that Serbian has different sentence patterning than English in cases when the illocutionary adverb iskreno is followed by focalized expression.

(6e) Honestly, HIS MONEY (*honestly) you should have asked for, not his car.

$\mathrm{IP} \rightarrow$ ForceP $-\mathrm{NP}-(*$ ForceP $)-\mathrm{NP}-\mathrm{AuxP}-\mathrm{AuxP}-\mathrm{VP}-\mathrm{NP}$

(6s) a. Iskreno, trebalo je da tražiš NJEGOV NOVAC (*iskreno), ne njegova kola.

$\mathrm{IP} \rightarrow$ ForceP $-\mathrm{VP}-\mathrm{V}-\mathrm{NP}-($ *ForceP $)-\mathrm{NP}$

(6s) b. Iskreno, bolje da si mu tržila NOVAC (*iskreno), a ne kola.

$\mathrm{IP} \rightarrow$ ForceP - VP $\quad-\mathrm{NP}-\mathrm{V}-\mathrm{NP} \quad-\left({ }^{*}\right.$ ForceP $)-\mathrm{NP}$

Honestly/iskreno may occur in post-subject position too, that is, within the complementizer layer, as in $(7 \mathrm{e})$ and $(7 \mathrm{~s})$, or may follow the finite non-lexical verb, which is a clear case of its realization within the inflectional layer, as shown in (8e) and (8s). Sentences (7e) and $(7 \mathrm{~s})$ demonstrate that English and Serbian structure patterns may occasionally overlap.

(7e) He honestly believes that you are his friend.

$\mathrm{IP} \rightarrow \mathrm{NP}-$ ForceP $-\mathrm{V}-\mathrm{CP}$

(7s) On iskreno veruje da si mu prijatelj. 
$\mathrm{IP} \rightarrow \mathrm{NP}-$ ForceP $-\mathrm{V}-\mathrm{CP}$

(8e) He had never invited anyone to dinner at the house, for the simple reason that they never had anything he could honestly call dinner.

IP $\rightarrow$ Clause - NP- AuxP - ForceP - V - NP

(8s) On nikada nije nikoga pozvao u kuću na večeru iz jednostavnog razloga jer nikada nisu imali nešto što bi (on) mogao iskreno da nazove večerom.

$\mathrm{IP} \rightarrow$ Clause $\quad-$ AuxP-(NP)-AuxP - ForceP - V - NP

Example (9e) illustrates that the illocutionary adverb honestly may occupy a postverbal position in English, whereas sentences $(9 \mathrm{~s} \mathrm{a}, \mathrm{b})$ show that the adverb iskreno cannot assume this position in Serbian but may occur either in the post-subject position or the front sentence position. Limitations in adverb placement in different languages impose close consideration of adverb constraints in languages, because they help us specify the base positions of certain adverb subclasses. Examples $(9 \mathrm{~s}$ a,$b)$ therefore demonstrate that, in Serbian, typical positions for the illocutionary adverb are within the complementizer layer. Analysing distributional ranges of briefly-type adverbs and honestly-type adverbs, Haumann (2007:341) concludes that the distributional range of briefly-type adverbs is narrower than that of honestly-type adverbs, and that briefly is banned from positions lower than NegP (e.g. *They hadn't briefly been entertaining this stupid idea) and nonfinite non-lexical verbs (e.g. * They will have seriously been (seriously) claiming that ... ). These examples prove that illocutionary adverbs have the status of assertive operators which are inmates of the complementizer layer and which take scope over the entire proposition. Examples $(9 \mathrm{~s} \mathrm{a}, \mathrm{b})$ support this claim for Serbian illocutionary adverb iskreno. To explain how English illocutionary adverbs are realized in postverbal position, Haumann (2007:341) maintains that they merge within empty VP structure, where they are licensed by forming a representational chain with the expletive assertion operator in specForce(Fin)P. She also shows later in her 2007 book that the empty VP structure may be applied to all speakeroriented adverb subclasses which assume the final sentence-position.

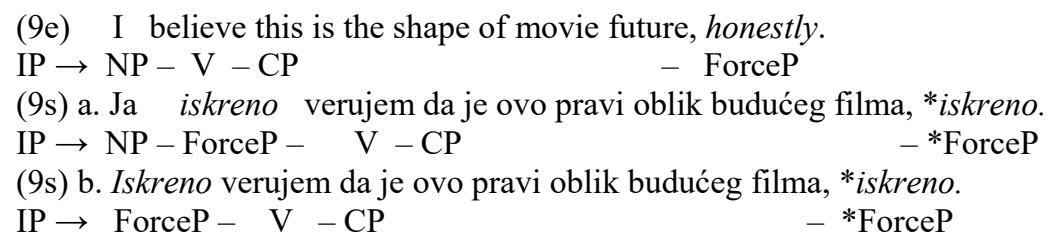

\subsubsection{Evaluative Adverbs}

Palmer (1968:12ff) and Ernst (2002:76) state that the speaker uses evaluative adverbs to evaluate a given state of affairs with respect to her/his standards. Haumann (2007:346f.) specifies constraints of evaluative adverbs. She shows that they are barred from occurring within the scope of interrogative operators (e.g. *Can he luckily take a joke?), counterfactual operators (e.g. *Had he had more self-esteem, he luckily could have taken a joke) and sentential negation (e.g. *He cannot luckily take a joke), as well as from following focalized constituents (e.g. Fortunately, SO HOPELESS (*fortunately) was (*fortunately) [his] attempt at shoplifting [...] that the manager finally let him go), and nonfinite non-lexical verbs (*You should have ideally eaten less). Ernst (2002:100) explains that the occurrence of evaluative adverbs in these cases would mean that the speaker creates a contradiction of the truth of the proposition. As evaluative adverbs take scope over true propositions, i.e. facts, they may be called factive operators. The relation between 
factivity and finiteness makes us understand that evaluative adverbs are merged as specifiers into FinP, below ForceP. To prove this, Haumann provides further evidence: evaluative adverbs occur within the scope of the declarative complementizer that (I believe of course that ideally chimps should live freely ...), after relative operators (... she opened her new copy of the Church Times which fortunatelly she had in her bag) and after topicalized constituents (She said that) temptation, fortunately, she could resist) (adapted from Haumann 2007:347).

The following examples show that evaluative adverbs may assume the sentence-initial position (10e, 10s a and $13 \mathrm{~s} \mathrm{c})$, the post-subject position (10s b and 11e), the position after the finite non-lexical verb $(11 \mathrm{~s}, 12 \mathrm{e}, 12 \mathrm{~s}$ and $13 \mathrm{~s} \mathrm{~b})$ and the sentence-final position (13e and $13 \mathrm{~s}$ a). The adverb ideally has been translated as najviše in (12s), which suggests that the semantics of English sentences containing evaluative adverbs may result in adjectives in Serbian equivalents. As for the sentence-final occurrences of English evaluative adverbs, Haumann (2007:351) claims that they are not right-adjoined but are merged into structure as the complement of an empty verbal head, $\mathbf{V}$, by forming a representational chain within the factive operator in specEvalP. Examples (13s a, b, c) show that Serbian allows a more flexible adverb distribution and that the position of the adverb nažalost in syntactic structure does not change the meaning of the sentence. Examples $(13 \mathrm{~s} \mathrm{a}, \mathrm{b})$ indicate that the adverb specifies the whole proposition, no matter whether it is placed at the beginning of the sentence or at the end of the sentence. That said, we can conclude that it is logical that the adverb is left-joined.

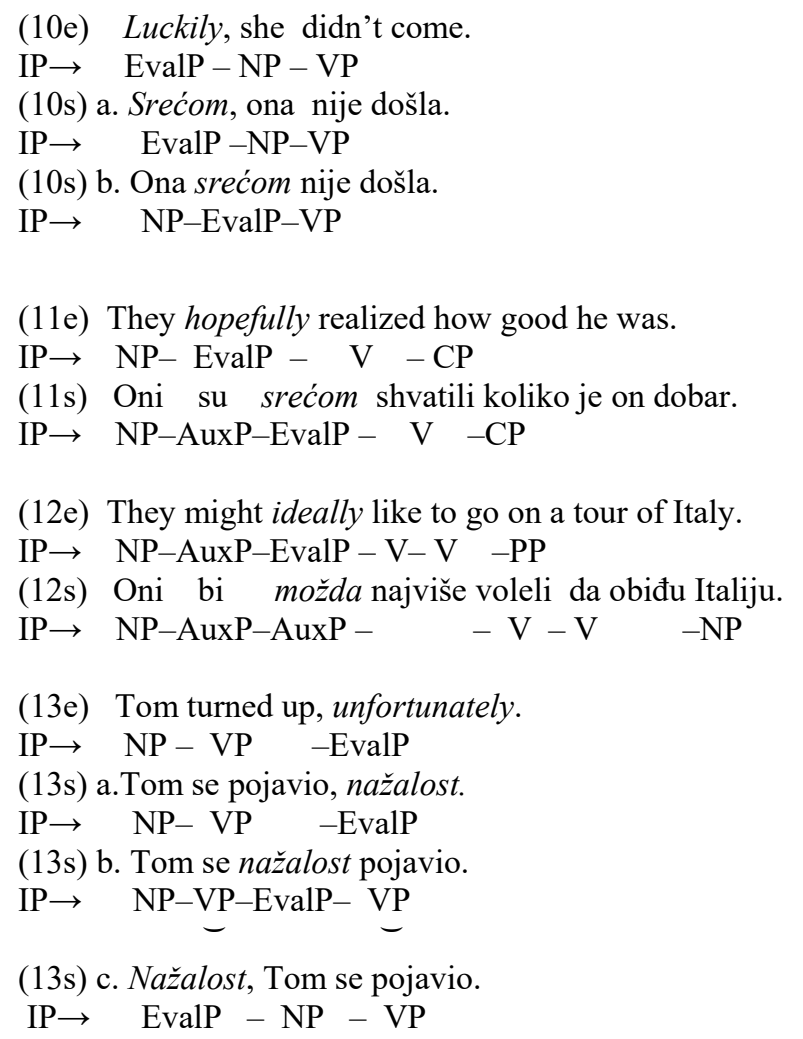

\subsubsection{Evidential Adverbs}

Evidential adverbs express degrees of certitude of the speaker's subjective perception of the truth of a proposition. The evidential adverbs (EvidP) obviously/ocito may be placed in the 
initial-sentence position in both languages, as in (14e) and (14s), though it is obvious that the rest of the sentence patterning differs in the two languages.

(14e) Obviously if you are worried about someone's safety, you should dial 999.

$\mathrm{IP} \rightarrow$ EvidP - Clause $\quad-\mathrm{NP}-\mathrm{AuxP}-\mathrm{V}-$

(14s) Očito je da bi, ako ste zabrinuti za nečiju bezbednost, bilo potrebno da pozovete broj 999.

$\mathrm{IP} \rightarrow \underset{\mathrm{NP}}{\text { EvidP-V}-\mathrm{VP}-\text { Clause }}$

$-\mathrm{VP} \quad-\mathrm{V}$

In strings (15e) and (15s), the adverbs assume the post-subject position. These examples illustrate that English and Serbian can have nearly identical clause patterning with one apparent difference: in sentence (15e), the negation is over self-control, while in (15s) the negation is over the lexical verb.

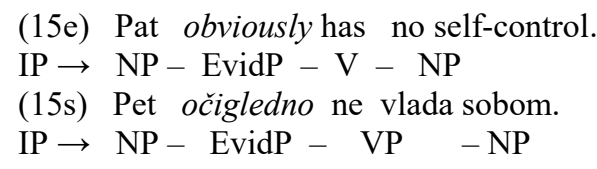

The adverbs obviously/očigledno may also occupy the position after the lexical verb, as shown in (16e) and (16s). These examples illustrate that English and Serbian sentences may share the same patterning.

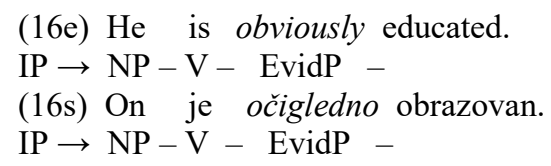

Example (17e) contains the evidential adverb surely, placed at the end of the sentence. Haumann (2007:357) demonstrates that the evidential adverb is realized within empty structure VP and licensed by forming a representational chain with the expletive operator in specEvidP. In contrast, example $(17 \mathrm{~s}$ a) shows that zaista is barred from occurring in the final position, but can assume the position after the lexical verb, as illustrated by $(17 \mathrm{~s} \mathrm{~b})$.

(17e) She is only a child, surely.

$\mathrm{IP} \rightarrow \mathrm{NP}-\mathrm{V}-\mathrm{PrtP}-\mathrm{NP}$-EvidP

$(17 \mathrm{~s})$ a. Ona je samo dete, *zaista

$\mathrm{IP} \rightarrow \quad \mathrm{NP}-\mathrm{V}-\mathrm{PrtP}-\mathrm{NP}-*$ EvidP

$(17 \mathrm{~s})$ b. Ona je zaista samo dete.

$\mathrm{IP} \rightarrow \mathrm{NP}-\mathrm{V}-$ EvidP-PrtP-NP

\subsubsection{Epistemic Adverbs}

Biber et al. (1999:854) consider epistemic markers to be "adverbs which express the speaker's judgment about the certainty, reliability and limitations of the proposition." Haumann (2007:365) claims that possibly and probably "structurally, though probably not pragmatically, make perfect VP-inmates, and maybe as a head is barred from assuming a specifier position 
within VP." Our analysis presented below shows how these adverbs and their Serbian equivalents pattern.

Examples (18e) and (18s) demonstrate that the epistemic adverbs (EpiP) possibly and moguće may assume the initial sentence position, but cause different sentence patterning in the two languages analysed.

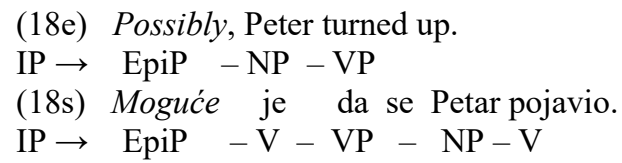

Sentence (19e) illustrates that the adverb probably may occupy the post subject position. In (19s), the adverb verovatno appears in the front sentence position, although Njima su verovatno bile potrebne glumice za tu vrstu stvari is acceptable, where verovatno occurs within the inflectional layer.

(19e) They probably needed actresses for that sort of thing.

$\mathrm{IP} \rightarrow \mathrm{NP}-\mathrm{EpiP}-\mathrm{VP}-\mathrm{NP}-\mathrm{PP}$

(19s) Verovatno su im bile potrebne glumice za tu vrstu stvari.

$\mathrm{IP} \rightarrow \mathrm{EpiP}-\mathrm{VP}-\mathrm{NP}-\mathrm{VP} \quad-\mathrm{NP} \quad-\mathrm{PP}$

Epistemic adverbs may assume the position between two auxiliaries too, as illustrated by (20e). The Serbian translation (20s) shows that verovatno occupies the position before the negative form of the finite non-lexical verb. Example (20s) illustrates that Serbian sentences can contain two negations.

(20e) On reflection, none of the family could possibly have chosen it.

$\mathrm{IP} \rightarrow \quad \mathrm{PP} \quad-\mathrm{NP} \quad-\mathrm{AuxP}-($ EpiP) -AuxP $-\mathrm{V}-\mathrm{NP}$

(20s) Posle razmišljanja, niko od članova porodice verovatno ne bi to izabrao.

$\mathrm{IP} \rightarrow \quad \mathrm{PP} \quad-\quad \mathrm{NP} \quad-($ EpiP $)-\mathrm{AuxP}-\mathrm{NP}-\mathrm{V}$

The adverb possibly may also appear in the postverbal position, as in (21e), whereas in the equivalent Serbian translation verovatno occurs in the sentence-initial position, as shown in (21s), and the terminal adverb tada is introduced to express the exact meaning of the sentence. In other words, example (21s) suggests that semantics has an impact on syntax and that it requires the inclusion of new elements into the sentence and changes its structure to a certain degree.

(21e) It was possibly the first time the BBC had had to take other eqipment out of service ...

$\mathrm{IP} \rightarrow \mathrm{NP}-\mathrm{V}-($ EpiP) - Temp $-\mathrm{NP}-\mathrm{AuxP}-\mathrm{V}-\mathrm{V}-\mathrm{NP} \quad-\mathrm{PP}$

(21s) Veorovatno je BBC tada morao prvi put da uzme drugu opremu van upotrebe

$\mathrm{IP} \rightarrow{ }^{\cdots}($ EpiP $) \quad-\mathrm{V}-\mathrm{NP}-\mathrm{Temp}-$ AuxP-Temp $-\mathrm{V}-\mathrm{NP}-\mathrm{PP}$

Examples (22e) and (22s a) show that maybe and možda are not acceptable in the final sentence position, unless they are stylistically marked. In sentence $(22 \mathrm{~s} b)$, možda occurs in the sentence-initial position, although it is possible to say On će me možda posetiti, where možda occurs within the inflectional layer.

??? (22e) He'll look me up, maybe. 


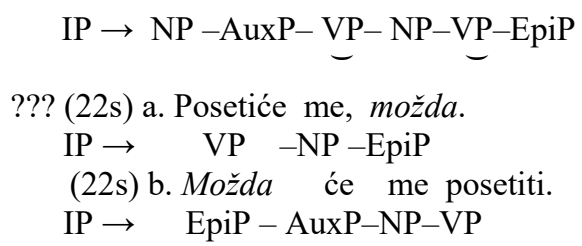

Example (23e), however, illustrates that maybe can occupy the initial position. Its equivalent in Serbian, možda, also assumes this position, as shown by (23s).

(23e) Maybe we even passed each other in the supermarket.

(23s) Možda smo čak prošli jedni pored drugih u samousluzi.

Maybe and možda preferably occur in the sentence-initial position and not in the epistemic adverb's base position within the inflectional layer, as Haumann (2007:361) also states for maybe. She explains that maybe originates as the head of EpiP and is too verbal-head-like, which helps us understand why maybe and možda act differently in syntax from other epistemic adverbs.

We would like to end this Section by pointing out that a framework for our analysis was found in Haumann's study (2007), which was built on the findings of her peers dealing with adverbs previously.

\section{Conclusions}

The investigation conducted in this paper suggests that all subclasses of speaker-oriented adverbs may be realized within the complementizer layer and the inflectional layer in both languages, and that only some of them may occur in postverbal position. Examples, containing the illocutionary adverb iskreno, the evidential adverb zaista and the epistemic adverbs možda and maybe in the sentence final position, demonstrate that the adverbs analysed are barred from occurring in this position. The fact that maybe and možda do not preferably occupy the epistemic adverb's base position within the inflectional layer points to the conclusion that they are too verbal-head-like and that they originate as the head of EpiP. It is therefore possible to claim that English epistemic adverbs are in most cases integrated into the inflectional layer, and Serbian epistemic adverbs tend to occur in the sentence-initial position.

Our next conclusion refers to the interplay between adverb syntax and semantics. Example (21s) suggests that semantics has an impact on syntax, since it requires the inclusion of a new element into the sentence, which changes its structure.

General conclusions, related to structural differences between the two languages under discussion, are that English and Serbian adverbs do not basically overlap structurally, although there are cases when they share the same patterning. It has been illustrated, too, that Serbian allows subject omission and two negations in a sentence, whereas English does not, and that adverb distribution in Serbian is more flexible than in English.

\section{References:}

Alexiadou, Artemis. 1997. Adverb Placement: A Case Study in Antisymmetric Syntax. Amsterdam: John Benjamins. Alexiadou, Artemis (Ed.). 2004. Taking up the Gauntlet. Adverbs across Frameworks. Lingua 114(6).

Bellert, Irena. 1977. "On semantic and distributional properties of sentential adverbs.” Linguistic Inquiry 8(2):337350. 
Biber, Douglas, Stig Johansson, Geoffrey Leech, Susan Conrad, and Edward Finegan. 1999. Longman Grammar of Spoken and Written English. Harlow, Essex: Pearson Education.

Cinque, Guglielmo. 1999. Adverbs and Functional Heads. A Cross-Linguistic Perspective. Oxford: Oxford University Press.

Cinque, Guglielmo. 2004. "Issues in adverbial syntax". Lingua 114(6):683-710. In Artemis Alexiadou (Ed.).

Chomsky, Noam. 1986. Barriers. Cambridge, MA: The MIT Press.

Dimković-Telebaković, Gordana. 2011. "Rečenični prilozi u srpskom i engleskom jeziku: uspostavljanje veze između sintakse i semantike priloga" in Zbornik radova sa V međunarodnog naučnog skupa održanog na Filološko-umetničkom fakultetu u Kragujevcu (29-30. X 2010), Srpski jezik, književnost, umetnost, Knjiga I, Književni (standardni) jezik i jezik književnosti. Miloš Kovačević (Ured.). Kragujevac: FILUM, pp. 207213.

Dimković-Telebaković, Gordana. 2013. English Adverbs in Theory and Practice. Timişoara: Editura Mirton.

Dimković-Telebaković, Gordana. 2015. "The Syntax and Semantics of English and Serbian Adverbs in Academic Written Discourse" in Academic Discourse across Cultures. Igor Lakić, Branka Živković and Milica Vuković (Eds.). Newcastle upon Tyne: Cambridge Scholars Publishing, pp. 163-179.

Ernst, Thomas. 2000. "On the order of event-internal adjunct" in Adverbs and Adjunction. Artemis Alexiadou and Peter Svenonius (Eds.). Potsdam: Universität Potsdam Press, pp. 33-49.

Ernst, Thomas. 2002. The Syntax of Adjuncts. Cambridge: Cambridge University Press.

Ernst, Thomas. 2004a. "Domain adverbs and the syntax of adjuncts" in Adverbial. The Interplay between Meaning, Context and Syntactic Structure. Jennifer R. Austin, Stefan Engelberg, and Gisa Rauh (Eds.). Amsterdam: John Benjamins, pp.103-129.

Ernst, Thomas. 2004b. "Principles of adverbial distribution in the lower clause" in Adverbs and Adjunction. Artemis Alexiadou and Peter Svenonius (Eds.). Potsdam: Universität Potsdam Press, pp. 755-777.

Frey, Werner and Karin Pittner. 1999. "Adverbialpositionen im deutsch-englischen Vergleich" in Sprachspezifische Aspekte der Informationsverteilung. Monika Doherty (Ed.). Berlin: Akademie Verlag, pp. 14-40.

Haider, Hubert. 2000. “Adverb placement - convergence of structure and licensing." Theoretical Linguistics 26(1/2): 95-134.

Haider, Hubert. 2004. "Pre- and postverbial adverbials in OV and VO." Lingua 114(6):779-807. In Artemis Alexiadou (Ed.).

Haumann, Dagmar. 2007. Adverb Licensing and Clause Structure in English. Amsterdam/ Philadelphia: John Benjamins.

Jackendoff, Ray. 1972. Semantic Interpretation in Generative Grammar. Cambridge, MA: The MIT Press.

Kayne, Richard. 1994. The Antisymmetry of Syntax. Cambridge, MA: The MIT Press.

Laenzlinger, Christopher. 1996. "Adverb syntax and phrase structure" in Configurations: Essays on Structure and Interpretation. Anna-Maria Di Sciullo (Ed.). Somerville: Cascadilla Press, pp. 99-112.

Laenzlinger, Christopher. 1998. Comparative Studies in Word Order Variation. Adverbs, Pronouns, and Clause Structure in Romance and Germanic. Amsterdam: John Benjamins.

Larson, Richard. 1988. "On the double object construction.” Linguistic Inquiry 19(3):335-391.

McConnell-Ginet, Sally. 1982. "Adverbs and Logical Form.” Language 58(1):144-184.

Palmer, Frank R. 1968. A Linguistic Study of the English Verb. London: Longmans.

Rakowski, Andrea and Lisa Travis. 2000. "V-initial languages: X or XP movement and adverbial placement" in The Syntax of Verb Initial Languages. Andrew Carnie and Eithne Guilfoyle (Eds.). Oxford: Oxford University Press, pp. 117-141.

Travis, Lisa. 1988. "The syntax of adverbs." McGill Working Papers in Linguistics - Special Issue on Comparative Germanic Syntax 20:280-310.

\section{Other sources:}

British National Corpus (BNC). [Online]. Available: http://sara.natcorp.ox.ac.uk/lookup.html

\section{Acknowledgments}

This paper is based on a research conducted within the project Description and Standardization of Contemporary Serbian, Grant No. 178021, funded by the Ministry of Education, Science and Technological Development of the Republic of Serbia and carried out at the Serbian Academy of Sciences and Arts. 


\section{Note on the author}

Dr Gordana Dimković-Telebaković is Professor of English at the University of Belgrade. Her latest books include: Some Elements of English Grammar (2nd edn. 2012), English Adverbs in Theory and Practice (2013), Studies on English and Serbian Language (2013), English in Transport and Traffic Engineering (6th edn. 2015) and Testovi, zadaci i teme iz engleskog jezika [Tests, Examination Papers and Essay Topics in English] (6th edn. 2015). In 2013, she edited a volume on Foreign Language in Transport and Traffic Engineering Profession and Science. She has also published numerous papers nationally and internationally, and several articles and book chapters with prestigious publishers (John Benjamins, De Gruyter and Cambridge Scholars Publishing). 